\title{
Evaluation of arboviruses of public health interest in free-living non-human primates (Alouatta spp., Callithrix spp., Sapajus spp.) in Brazil
}

\author{
Tatiana Carneiro da Rocha ${ }^{[1]}$, Paulo Mira Batista ${ }^{[2],[3]}$, Renato Andreotti ${ }^{[4],}$ \\ Ana Caroline Dalla Bona ${ }^{[5]}$, Mário Antônio Navarro da Silva ${ }^{[5]}$, Rogério Lange ${ }^{[6]}$, \\ Walfrido Kühl Svoboda ${ }^{[7]}$ and Eliane Carneiro Gomes ${ }^{[1]}$
}

[1]. Programa de Pós-Graduação em Ciências Farmacêuticas, Universidade Federal do Paraná, Curitiba, Paraná, Brasil. [2]. Coordenadoria Estadual de Vigilância Epidemiológica, Secretaria Estadual do Mato Grosso do Sul, Campo Grande, Mato Grosso do Sul, Brasil. [3]. Programa de Pós-Graduação em Doenças Infecciosas e Parasitárias, Universidade Federal do Mato Grosso do Sul, Campo Grande, Mato Grosso do Sul, Brasil. [4]. Embrapa Gado de Corte, Empresa Brasileira de Pesquisa Agropecuária, Campo Grande, Mato Grosso do Sul, Brasil. [5]. Departamento de Zoologia, Setor de Ciências Biológicas, Universidade Federal do Paraná, Curitiba, Paraná, Brasil. [6]. Departamento de Medicina Veterinária, Setor de Ciências Agrárias, Universidade Federal do Paraná, Curitiba, Paraná, Brasil. [7]. Instituto Latino-Americano de Ciências da Vida e da Natureza, Universidade Federal da Integração Latino-Americana, Foz do Iguaçu, Paraná, Brasil.

\begin{abstract}
Introduction: The aim of the present study was to evaluate the presence of arboviruses from the Flavivirus genus in asymptomatic free-living non-human primates (NHPs) living in close contact with humans and vectors in the States of Paraná and Mato Grosso do Sul, Brazil. Methods: NHP sera samples (total $\mathrm{n}=80$, Alouatta spp. $\mathrm{n}=07$, Callithrix spp. $\mathrm{n}=29$ and Sapajus spp. $\mathrm{n}=44$ ) were screened for the presence of viral genomes using reverse transcription polymerase chain reaction and $10 \%$ polyacrylamide gel electrophoresis techniques. Results: All of the samples were negative for the Flavivirus genome following the $10 \%$ polyacrylamide gel electrophoresis analysis. Conclusions: These negative results indicate that the analyzed animals were not infected with arboviruses from the Flavivirus genus and did not represent a risk for viral transmission through vectors during the period in which the samples were collected.
\end{abstract}

Keywords: Non-human primates. Arbovirus. RT-PCR. Zoonosis.

\section{INTRODUCTION}

The arbovirus life cycle is responsible for viral maintenance in the environment and represents a risk for human populations that live in close contact with wildlife, given that most arboviruses can cause zoonotic infections. Non-human primates (NHPs) are important wild hosts of arboviruses and can act as indicators of circulating viruses with public health significance ${ }^{(1)(2)(3)}$.

Most NHPs inhabit areas of tropical forests, and contact with humans constitutes a high risk of viral transmission through vectors. The risk of arbovirus transmission has increased recently due to several factors, including climate change, human population growth, unplanned urbanization, the construction

Corresponding author: Dra. Tatiana Carneiro da Rocha. Laboratório de Saúde Pública e Saúde Ambiental/PPCF/UFPR. Av. Lothário Meissner 632, 80210-170 Curitiba, Paraná, Brasil.

Phone: 5541 3360-4073; Fax: 5541 3360-6726

e-mail: tcarneiro.rocha@gmail.com

Received 24 January 2015

Accepted 11 March 2015 of new highways, ecotourism, rural tourism and fishing tourism $^{(3)(4)(5)(6)}$. A number of these viruses carry a high epidemic risk, which could have negative social and economic impacts and pose a threat to public health ${ }^{(7)(8)}$.

The Flavivirus genus (Flaviviridae family) comprises some of the major arboviruses that are potentially pathogenic for humans worldwide ${ }^{(9)}$. These viruses can cause encephalitis, hemorrhage, liver disease and severe fever in vertebrate animals, including humans ${ }^{(10)}$. Indeed, the Flavivirus genus presents a serious public health threat in Brazil and throughout the world due to its wide geographical expansion, epidemic potential and high morbidity and mortality rates ${ }^{(11)}$.

According to the Brazilian Ministry of Health, this country registered more than two million dengue virus cases in 2013, which led to 213 deaths ${ }^{(12)(13)}$. Additionally, 324 cases of yellow fever, which led to 155 deaths, were recorded in the ten-year period from $2000-2010$, with a high lethality rate of $48 \%^{(14)}$.

Therefore, the aim of the present study was to evaluate the presence of arbovirus genomes from the Flavivirus genus in sera samples from asymptomatic free-living NHPs inhabiting areas in close contact with humans and vectors in the States of Paraná and Mato Grosso do Sul, Brazil. 


\section{METHODS}

\section{Study area}

The present study was performed in six study areas located in four different municipalities of the States of Paraná and Mato Grosso do Sul, Brazil (Figure 1). The first study area comprised a fragment of forest within the Porto Rico municipality, which is located between the Northwestern region of the State of Paraná and the Southeast region of the State of Mato Grosso do Sul, on the upper Paraná River in Brazil. This region consists of islands and sub-tropical forest reserves. The Porto Rico municipality is located in the Northwestern region of the State of Paraná $\left(22^{\circ} 46^{\prime} 20^{\prime \prime} \mathrm{S}, 53^{\circ} 16^{\prime} 01^{\prime \prime} \mathrm{W}\right)$. This municipality is located in a region widely known for fishing tourism activities, in which visitors have close contact with animals, including free-living NHPs.

The second study area corresponded to Bosque da Companhia de Energia Elétrica do Estado do Paraná (2525'57" $\left.\mathrm{S}, 49^{\circ} 18^{\prime} 06^{\prime \prime} \mathrm{W}\right)$, and the third study area included Barigui Park $\left(25^{\circ} 25^{\prime} 37^{\prime \prime} \mathrm{S}, 49^{\circ} 18^{\prime} 28^{\prime \prime} \mathrm{W}\right)$. In both of these locations, the animals have close contact with vectors and humans, particularly in Barigui Park, where tourist activities attract many visitors every year. Both places are located in the City of Curitiba, the capital of the State of Paraná, which is located in the Eastern region of the state.

The fourth study area comprised a fragment of forest in the Pantanal region, which is a seasonal tropical wetland with an area of approximately $140,000 \mathrm{~km}^{2}$. This area is considered to be one of the largest freshwater ecosystems in the world. The Pantanal region is located within the Bodoquena municipality in the Southwest region of the State of Mato Grosso do Sul (20³2'19" S, 56²4'54" W).

The fifth study area comprised a forest fragment near the BR 163 highway (23⒌'15" S, 54 $\left.{ }^{\circ} 18^{\prime} 9^{\prime \prime} \mathrm{W}\right)$, which travels from Santarém, State of Pará, to Tenente Portela, State of Rio Grande do Sul. This locality is characterized as a rest place and a stop for truckers from all over the country, and because contact between humans and animals occurs here, it represents a high-risk interface for disease transmission. The sixth study area comprised a forest fragment where free-living NHPs had adapted to human contact, and very close contact was known to occur between species. Both the fifth and sixth study areas are located within the Mundo Novo municipality (23⒌ $56^{\prime} 16^{\prime \prime} \mathrm{S}$, $\left.54^{\circ} 16^{\prime} 15^{\prime \prime} \mathrm{W}\right)$, which is located in the Southwest region of State of Mato Grosso do Sul, where it borders the City of Guaíra, State of Paraná, and the Paraguayan City of Salto del Guairá.

\section{Non-human primates}

From November 2012 to January 2013, NHP blood samples from three different genera, including Alouatta $(\mathrm{n}=$ 07), Callithrix $(\mathrm{n}=29)$ and Sapajus $(\mathrm{n}=44)$, were collected and stored at $-70^{\circ} \mathrm{C}$ until laboratory processing. The Alouatta $(\mathrm{n}=07)$ and Sapajus $(\mathrm{n}=19)$ NHPs were captured in the Porto Rico municipality and represented a native population of that area.

The Callithrix $(\mathrm{n}=29)$ NHPs were captured in two locations in the City of Curitiba; 11 were captured from the Bosque da

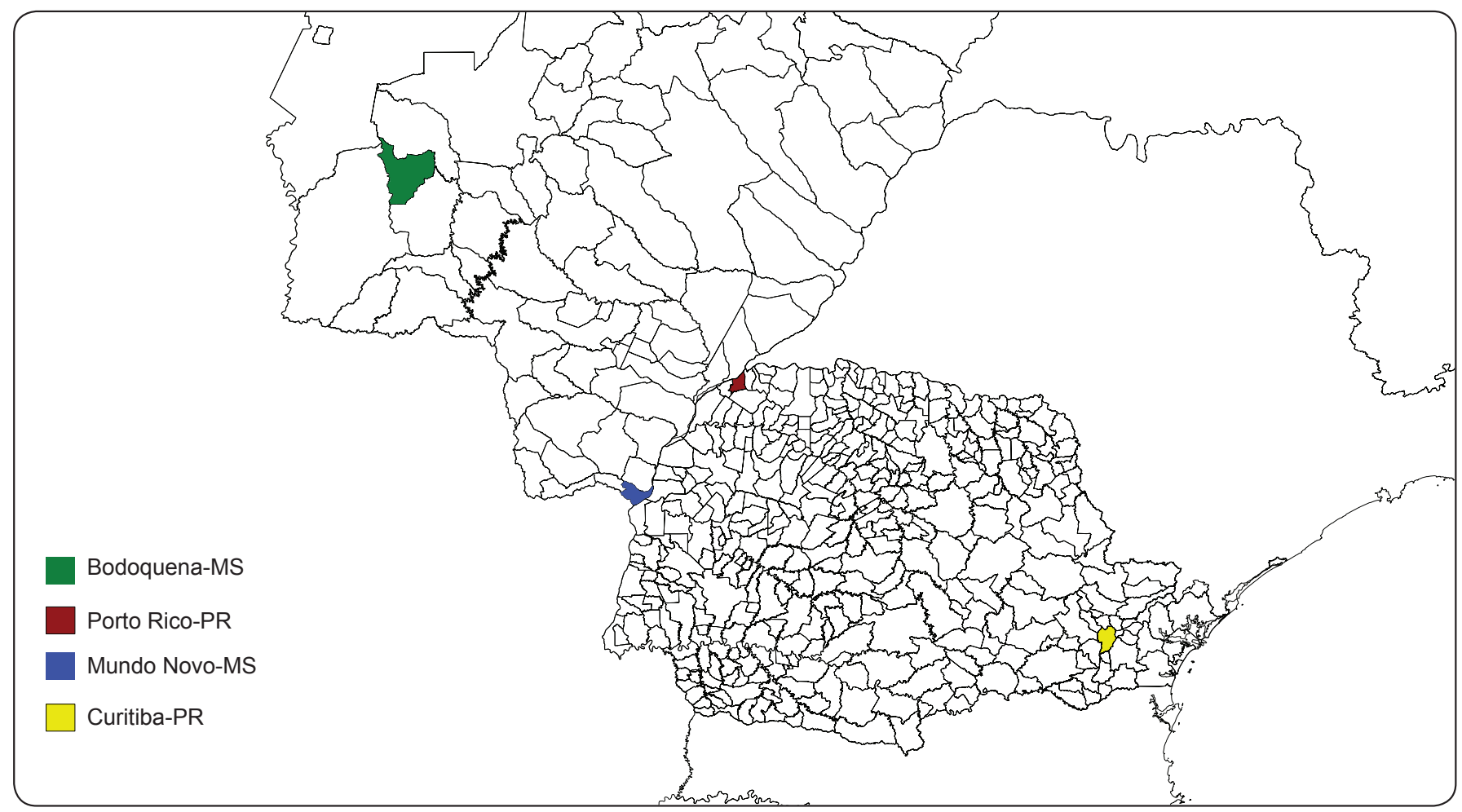

FIGURE 1 - The geographical locations of the four municipalities in the States of Paraná (PR) and Mato Grosso do Sul (MS), Brazil. 
Companhia de Energia Elétrica do Estado do Paraná, and 18 were captured from Barigui Park.

Finally, 25 Sapajus NHPs were captured in the Bodoquena municipality $(\mathrm{n}=3)$, as well as from forest areas of the Mundo Novo municipality $(n=22)$, both of which are located in the State of Mato Grosso do Sul.

\section{Viral RNA extraction}

Viral ribonucleic acid was extracted using the QIAmp Viral Mini Kit (Qiagen, USA), according to the manufacturer's instructions.

\section{Reverse transcription polymerase chain reaction}

For the reverse transcription and complementary deoxyribonucleic acid reactions, $16.5 \mu \mathrm{l}$ of RNA and $1 \mu \mathrm{l}$ of Flav 200R primer $(50 \mathrm{pmol})$ were placed in a thermocycler at $70^{\circ} \mathrm{C}$ for 5 minutes. The samples were then removed from the thermocycler and placed in an ice bath. Subsequently, $5 \mu$ of $5 \mathrm{x}$ buffer [250mM Tris- $\mathrm{HCl}$ ( $\mathrm{pH} 8.3$ ), $375 \mathrm{mM} \mathrm{KCl,} 15 \mathrm{mM} \mathrm{MgCl} 2$ ], $0.5 \mu \mathrm{l}$ of deoxyribonucleotide triphosphate $(200 \mathrm{mM})$ and $20 \mathrm{U}$ of avian myeloblastosis virus reverse transcriptase enzyme (Promega) were added. Finally, autoclaved Milli-Q water was added to achieve a final volume of $25 \mu$. The final reaction was performed in a thermocycler at $42^{\circ} \mathrm{C}$ for 90 minutes followed by $70^{\circ} \mathrm{C}$ for 15 minutes.

The amplification reaction was prepared in a final volume of $25 \mu \mathrm{l}$ using $3 \mu \mathrm{l}$ of previously obtained cDNA, $2.5 \mu \mathrm{l}$ of $10 \mathrm{x}$ buffer [Tris- $\mathrm{HCl} 200 \mathrm{mM}(\mathrm{pH} 8.4) ; \mathrm{KCl} 500 \mathrm{mM}$ ], $1 \mu$ l of Flav $100 \mathrm{~F}$ primer $(20 \mathrm{pmol}), 1 \mu \mathrm{l}$ of Flav 200R primer (20pmol), $1.5 \mu \mathrm{l}$ de $\mathrm{MgCl}_{2}(25 \mathrm{mM}), 0.5 \mu \mathrm{lde}$ dNTPs $(200 \mathrm{mM})$ and $3 \mathrm{U}$ of AmpliTaq Gold DNA polymerase (Applied Biosystems). The amplification protocol consisted of 35 cycles at $94^{\circ} \mathrm{C}$ for 30 seconds, $55^{\circ} \mathrm{C}$ for 1 minute, and $72^{\circ} \mathrm{C}$ for 2 minutes. The primers have been described previously in the literature ${ }^{(15)}$. The same procedure was used for the positive (yellow fever virus 17D vaccine strain) and negative (Milli-Q water) controls.

\section{Electrophoresis}

The amplicons were subjected to $10 \%$ polyacrylamide gel electrophoresis with molecular weight markers and positive and negative controls.

\section{Ethical considerations}

The use of animals in the present study was authorized by Instituto Brasileiro do Meio Ambiente e dos Recursos Naturais Renováveis (IBAMA) under numbers 104/04, 23065-2/10, 29430-1/11 and the Ethics Committee for Animal Experimentation of the Universidade de Londrina (protocol number 34/05) and of the Universidade Federal do Mato Grosso do Sul (protocol number 462/12).

\section{RESULTS}

All of the samples were negative for arbovirus genomes from the Flavivirus genus (Figure 2, Figure 3 and Figure 4). These results demonstrated that the analyzed NHP population did not exhibit Flavivirus infection during the period in which the samples were collected.

\section{DISCUSSION}

Despite the fact that the free-living NHPs studied herein inhabited areas close to human populations, which could favor the transmission of arboviruses through vectors, the present study showed that there was no Flavivirus transmission risk during the period in which the samples were collected. From a sanitary point of view, these data are relevant ${ }^{(16)}$, particularly

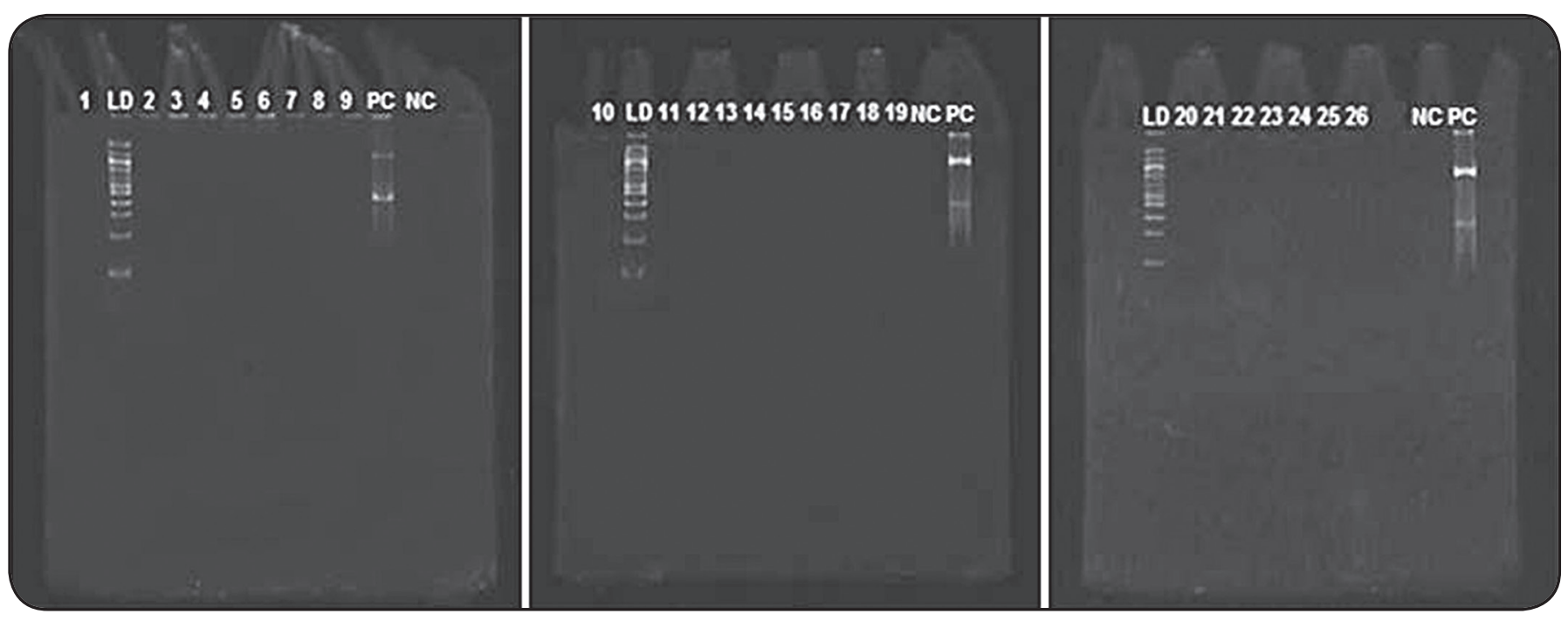

FIGURE 2 - The NHP samples (1-26) from Porto Rico municipality, State of Paraná, Brazil. NHP: non-human primate; LD (Ladder): 100 bp; NC: negative control; PC: positive control. 


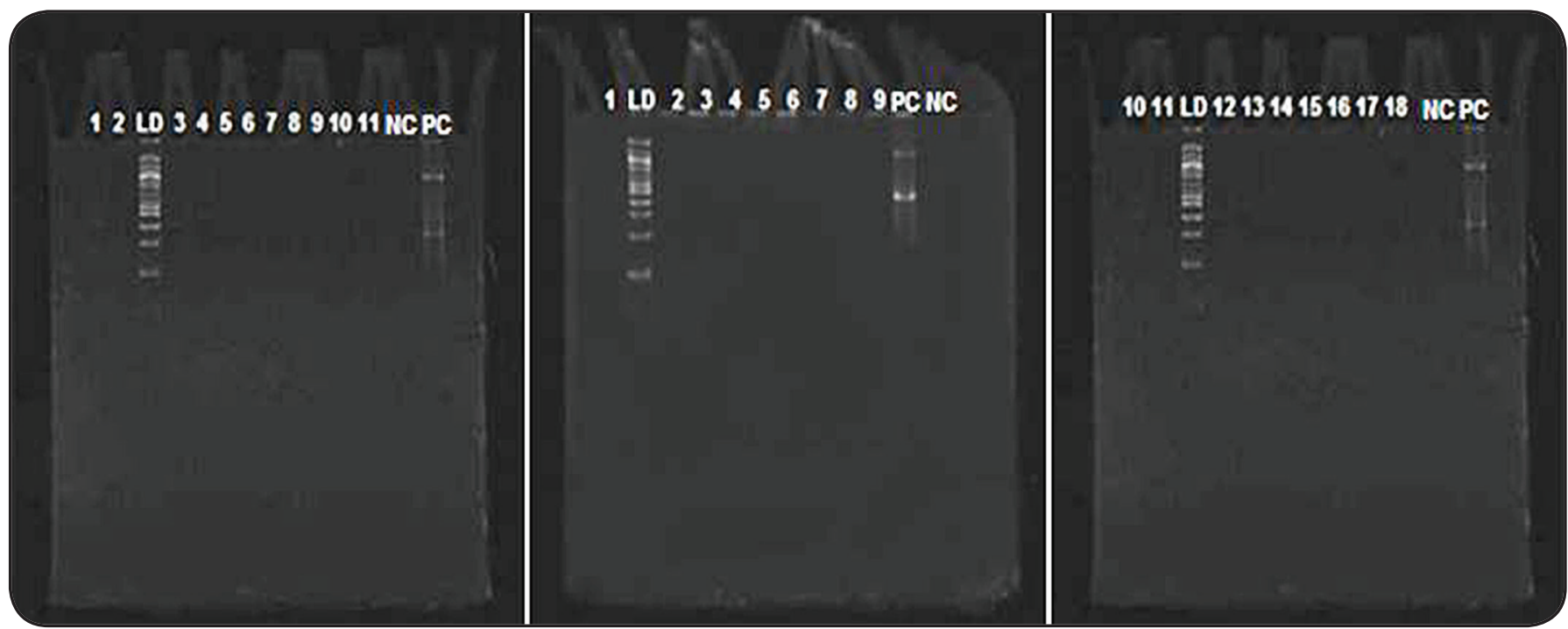

FIGURE 3 - The NHP samples (1-11) from Bosque da Companhia de Energia Elétrica do Estado do Paraná, Curitiba municipality, State of Paraná, Brazil. The NHP samples (1-18) from Barigui Park, Curitiba municipality, State of Paraná, Brazil. Note: NHP: non-human primate; LD (Ladder): 100 bp; NC: negative control; PC: positive control.

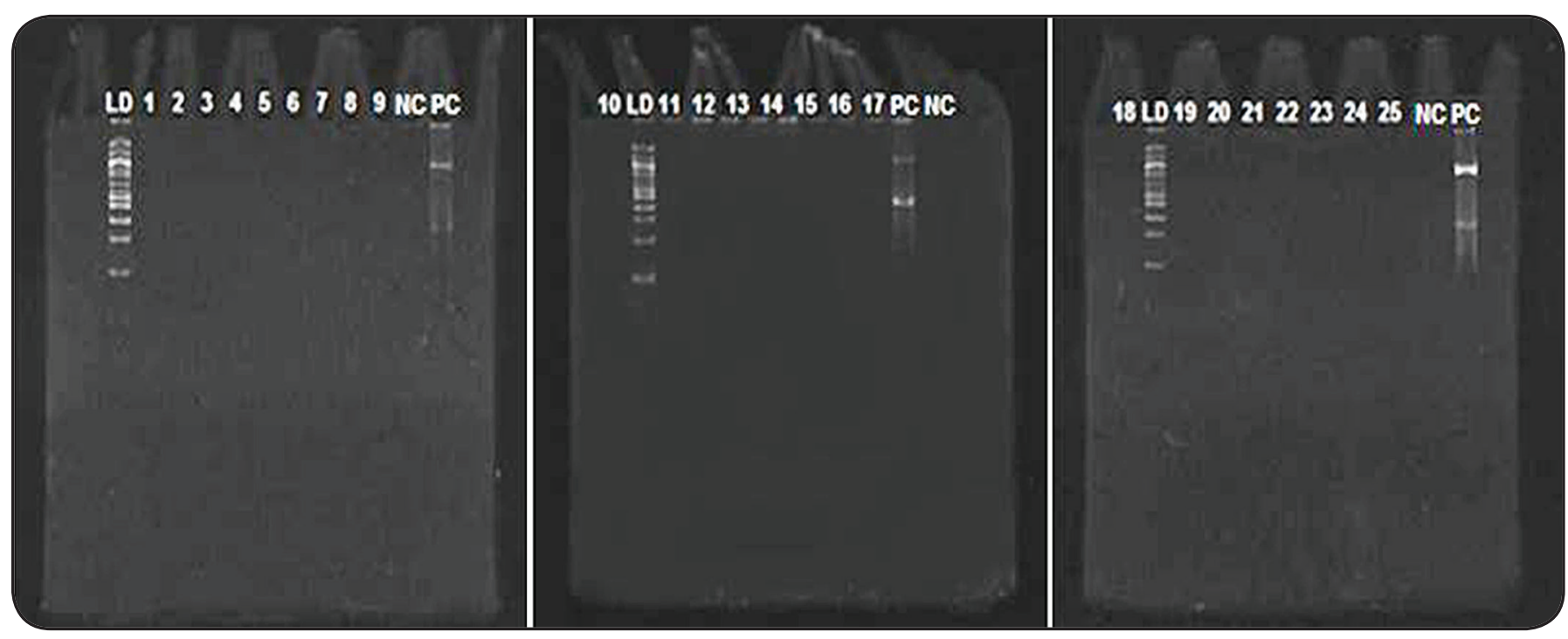

FIGURE 4 - The NHP samples (1-22) from Mundo Novo municipality, State of Mato Grosso do Sul, Brazil. The NHP samples (23-25) from Bodoquena municipality, State of Mato Grosso do Sul, Brazil. Note: NHP: non-human primate; LD (Ladder): 100 bp; NC: negative control; PC: positive control.

when considering that many free-living NHPs have been captured in parks and forest areas where tourism is popular. Thus, these animals live in close contact with visitors and residents in these areas and carry the potential for high viral transmission risk.

To investigate arbovirus circulation in free-living NHPs, several studies have been conducted in Brazil, including studies in the States of Paraná and Mato Grosso do Sul. However, these wild animal studies had limitations because they mainly assessed the distribution of seropositive animals by detecting antibodies and determining the exposure (or lack thereof) of the animals to the pathogens ${ }^{(17)}$.

In 2001, NHP deaths (Alouatta guariba) caused by the yellow fever virus were recorded in the State of Rio Grande do Sul ${ }^{(18)}$. From 2002 to 2007 , during the active surveillance of yellow fever in the same State, 181 NHPs were captured in different regions. Antibodies against encephalitis virus (Saint Louis) and Oropouche virus were detected in 16 and 1 NHPs, respectively ${ }^{(19)}$. Of the 133 NHPs captured in a study conducted in the border region between the States of Paraná 
and Mato Grosso do Sul, 21 were found to have Saint Louis encephalitis virus infections ${ }^{(2)}$, which suggested the involvement of these primates in the maintenance of this arbovirus in Southern Brazil ${ }^{(20)}$. Similarly, in the State of Mato Grosso do Sul, 65 NHPs were analyzed for the presence of antibodies against arboviruses (e.g., Flavivirus genus, Mayaro virus and Oropouche virus), and 18 animals showed positive test results ${ }^{(21)}$. In the same region, 16 NHP blood samples were examined, and five tested positive for antibodies against arboviruses, including Flavivirus $(\mathrm{n}=3)$, Mayaro $(\mathrm{n}=1)$ and Oropouche $(\mathrm{n}=1)^{(22)}$.

Due to the re-emergence of arbovirus infection in different areas, studies aiming to identify these viruses in their vectors and wild hosts are essential for active surveillance. Moreover, these studies are important with regard to public health, as they can predict epidemics, thereby reducing the negative impacts that epidemics can have on the health of the population and on

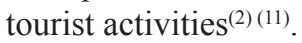

Anthropogenic activities can have a direct influence on the environment, causing rapid changes that enable the emergence of pathogens and diseases. Therefore, continuous monitoring of the pathogens that affect NHPs is important, especially in environments that are close to urban areas. Indeed, this preventive measure can have a direct effect on public health and the conservation of primate species.

\section{ACKNOWLEDGMENTS}

We thank Dr. Marcio Nunes at the Evandro Chagas Institute and the Graduate Program of Pharmaceutical Sciences Universidade Federal do Paraná.

\section{CONFLICT OF INTEREST}

The authors declare that there is no conflict of interest.

\section{FINANCIAL SUPPORT}

This study received support from the Coordination of Training of Higher Education Graduate Foundation [Coordenação de Aperfeiçoamento de Pessoal de Nivel Superior (CAPES)], Fundação Araucária and the Pharmaceutical Sciences graduate program - Universidade Federal do Paraná.

\section{REFERENCES}

1. Kowalewski MM, Salzer JS, Deutsch JC, Raño M, Kuhlenschmidt MS, Gillespie TR. Black and gold howler monkeys (Alouatta caraya) as sentinels of ecosystem health: patterns of zoonotic protozoa infection relative to degree of human-primate contact. Am J Primatol 2011; 73:75-83.

2. Svoboda WK. Vigilância de epizootias em primatas não-humanos (PNH) como instrumento de monitoramento de arboviroses e outras viroses de interesse em saúde pública. 136 p. (Doctors Thesis). Universidade Estadual de Londrina; 2007 Londrina.
3. Wolfe ND, Escalante AA, Karesh WB, Kilbourn A, Spielman A, Lal AA. Wild primate populations in emerging infectious disease research: The missing link? Emerg Infect Dis 1998; 4:149-158.

4. Gould EA, Higgs S. Impact of climate change and other factors on emerging arbovirus diseases. Trans R Soc Trop Med Hyg 2009; 103:109-121.

5. Gubler DJ. Human arbovirus infections worldwide. Ann N Y Acad Sci 2001; 951:13-24.

6. Vasconcelos PF, Travassos da Rosa APA, Rodrigues SG, Travassos da Rosa ES, Dégallier N, Travassos da Rosa JFS. Inadequate management of natural ecosystem in the Brazilian Amazon region results in the emergence and reemergence of arboviruses. Cad Saude Publica 2001; 17:155-164.

7. Blair CD, Adelman ZN, Olson K. Molecular strategies for interrupting arthropod-borne virus transmission by mosquitoes. Clin Microbiol Rev 2000; 13:651-661.

8. Figueiredo LTM. Emergent arboviruses in Brazil. Rev Soc Bras Med Trop 2007; 40:224-229.

9. Heinz FX, Stiasny K. Flaviviruses and their antigenic structure. J Clin Virol 2012; 55:289-295.

10. Monath TP, Heinz FX. Flaviviruses. In: Fields BN, Knipe DM, Howley M, editors. Fields Virology. Philadelphia: Lippincott, Williams \& Wilkins; 1996. p. 961-1032.

11. Figueiredo LTM. The Brazilian Flaviviruses. Microbes Infect 2000; 2:1643-1649.

12. Ministério da Saúde. Casos de Dengue, Brasil, Grandes Regiões e Unidades Federadas, 1990 a 2013. Brasília: Secretaria de Vigilância em Saúde. Sistema de Informação de Agravos de Notificação (2014a). Online at: http://portalsaude.saude.gov.br/ images/pdf/2014/marco/27/Casos-e-incid-dengue -ate-2013.pdf.

13. Ministério da Saúde. Óbitos por febre hemorrágica da Dengue, Brasil, Grandes Regiões e Unidades Federadas 1990 a 2013. Brasília: Secretaria de Vigilância em Saúde. Sistema de Informação de Agravos de Notificação (2014b). Online at: http://portalsaude. saude.gov.br/images/pdf/2014/marco/27/obitos-dengu-ate-2013. pdf.

14. Ministério da Saúde. Casos de Febre Amarela, Brasil, Grandes Regiões e Unidades Federadas 1990 a 2010. Brasília: Secretaria de Vigilância em Saúde. Sistema de Informação de Agravos de Notificação (2011). Online at: http://portal.saude.gov.br/portal/ arquivos/pdf/tabela_1_fa2010.pdf.

15. Maher-Sturgess SL, Forrester NL, Wayper PJ, Gould EA, Hall RA, Barnard RT, et al. Universal primers that amplify RNA from all three Flavivirus subgroups. Virol J 2008; 5:1-10.

16. Souza FM. Investigação de vírus entéricos de interesse em saúde pública (Rotavírus A, B e C, Norovírus e Sapovírus) em primatas não humanos em localidades do sul do Brasil. 132 p. (Masters Thesis). Universidade Federal do Paraná; 2011 Curitiba.

17. Thoisy B, Gardon J, Salas RA, Morvan J, Kazanji M. Mayaro virus in wild mammals, French Guiana. Emerg Infect Dis 2003; 9: 1326-1329.

18. Torres MAN, Santos E, Almeida MAB, Cruz LL, Sperb AF. Vigilância da febre amarela silvestre no Rio Grande do Sul. In: Boletim Epidemiológico da SESA-RS do Estado do Rio Grande do Sul. Porto Alegre, 2003, vol 6.

19. Almeida MAB, Santos E, Cardoso JC, Fonseca DF, Torres MAN, Cardoso LL. Vigilância da Febre Amarela e outras arboviroses através do monitoramento de primatas não humanos de vida 
livre no Rio Grande do Sul. Rev Soc Bras Med Trop 2008; 41 (supl I):173.

20. Batista PM, Andreotti R, Chiang JO, Ferreira MS, Vasconcelos PF. Seroepidemiological monitoring in sentinela animals and vectors as part of arbovirus surveillance in the State of Mato Grosso do Sul, Brazil. Rev Soc Bras Med Trop 2012; 45:168-173.

21. Batista PM. Arboviroses em primatas não humanos capturados em Mato Grosso do Sul. 89 p. (Masters Thesis). Universidade Federal do Mato Grosso do Sul; 2011 Campo Grande.
22. Batista PM, Andreotti R, Almeida OS, Marques AC, Rodrigues SG, Chiang JO, et al. Detection of arboviruses of public health interest in free-living New World primates (Sapajus spp.; Alouatta caraya) captured in Mato Grosso do Sul, Brazil. Rev Soc Bras Med Trop 2013; 46:684-686. 